B13 輸入外部寄生虫症としてのマダ二咬症への対応 内川公人（信州大学医寄生虫学）

Problems in identification of ticks imported on victims Kimito Uchikawa

寄生性節足動物は、一般に寄生期間（時間）が短いために、輸入されて治療の対象とな る寄生虫症を惹き起こすことは少なく、終生寄生虫と例外的に寄生期間の長いヒト七フバ エ、スナノミ、マダニ類、などが取り上げられてきただけである。これらの他にトコジラ ミによる輸入皮膚症の報告もあるが、原因種を実際に見ることは難しい。われわれは寄生 体の同定を要求されるが、宿主関係や分布域に関する情報があれば容易に同定できる種類 がある一方、マダ二類のように地域ごとに特異なファウナがあるために鑑別しにくいこと が多いあのがある。さらに、マダ二類では、成虫ばかりではなく、チマダニ属やキララマ ダ二属のように若虫や幼虫を含めた全活動㱓期の同定が要求されることがある。しかし、 これらの要求が叶えられず、属までの同定に留まる傾向にある日本の現状を、一つの問題 として取り上げたい。

\title{
B14 愛知県から分離された有毒フトゲッッガムシの性比について
}

角坂 照貴 (愛知医大・寄生虫) ・山本 正悟（宮崎県衛生環境研究所）

Sex ratios in Orientia tsutsugamushi-infected colonies of Leptotrombidium pallidum in Aichi Prefecture.

Kadosaka T. and Yamamoto S.

愛知県小原村大倉で採集されたフトゲッッガムシから 5 コロニー（5／74） のOrientia tsutsugamushi 保有コロニーを分離した。これらが保有するリケッチアはモノクローナ ル抗体を用いて同定した結果、Karp型と同定された。この有毒ッッガムシは雌が雄に優 先して出現したため 3 世代目の成虫を用いて雌雄の出現状况を調べた。その結果、国内の 他の地域のフトゲッッガムシで見られるような雄の出現頻度より東南アジアの他の種で見 られるような低い頻度であった。出現した 4 個体の雄は全てリケッチアを保有していた。 しかし 4 世代目から雄の頻度が高くなり 5 世代目にはリケッチアが見られなくなった。

$\begin{array}{rrrrrc}\text { Lot No. } & \text { 満腹落下数 } & \text { 成虫数 } & \text { 雌 } & \text { 雄 } & \text { 不明 } \\ 8 & 142 & 92 & 92 & 0 & 0 \\ 1 & 123 & 104 & 100 & 3 & 1 \\ 20 & 140 & 87 & 85 & 1 & 1 \\ 25 & 93 & 52 & 52 & 0 & 0\end{array}$

